\title{
Slovakia's transition to a market economy and the World Bank's engagement
}

\author{
Miroslav Beblavý
}

\section{INTRODUCTION}

This chapter presents an overall picture of the Slovakia's transition to a market economy during 1990s and 2000s and of the World Bank role in that transition. The chapter is divided into three sections. The first one presents the Slovak developments from a historical perspective, starting in 1990 and continuing until 2008. For each of the five periods presented, it tries to present both the macroeconomic context as well as the main policy developments with regard to the economy. The second section looks in detail at three special topics in the Slovakia's transition that are worth attention as they are of sufficient importance for understanding the country's development and they demonstrate idiosyncrasies, successes and failures of the Slovak experience. The topics are: growth, size of the state and equity; labor market outcomes; and industrial policy, privatization and FDI. They are presented in a comparative perspective, with regard to the other three Central European countries: the Czech Republic, Hungary and Poland. In the last section, the chapter examines the World Bank engagement.

\section{SECTION I: Timeline of the Slovak transition - from 1990 to 2008}

The section looks at the timeline of the Slovak transition from 1990 until 2008 as divided into five periods:

- 1990-1992: Early transition within Czechoslovakia

- 1992-1998: Independence and the stalled transition

- 1998-2002: Cleaning up the economy

- 2002-2006: Completing the transition - structural reform and EU accession

- 2006- : Distributing the fruits of growth - rupture or continuity?

The following table presents a list of all the Slovak governments since 1990 to facilitate reading by those not familiar with the recent Slovak history.

Table I.1: Governments of Slovakia, 1990-2008

\begin{tabular}{|l|l|}
\hline Years & Government \\
\hline $1990-1992$ & Mečiar I/Čarnogurský \\
\hline $1992-1994$ & Mečiar II \\
\hline 1994 & Moravčík \\
\hline $1994-1998$ & Mečiar III \\
\hline $1998-2002$ & Dzurinda I \\
\hline $2002-2006$ & Dzurinda II \\
\hline $2006-$ & Fico \\
\hline
\end{tabular}

Source: author

The political data are supplemented by selected economic indicators presented in 
Table I.2. Again, their point is in providing a single point of reference to reader not familiar with Slovakia and its economic development. ${ }^{1}$

Table I.2: Selected economic indicators in Slovakia, 1993-2007

[Insert table from the attached excel file]

Source: EBRD, Eurostat, IMF, Slovak Statistical Office

\section{0-92: Early transition within Czechoslovakia}

Slovakia started its transition as a part of the Czechoslovak federation. In November and December 1989, after a series of massive demonstrations and a general strike, the Communist Party of Czechoslovakia gave up power. The parliamentary election of June 1990 produced a clear majority in both parts of Czechoslovakia for parties that espoused pro-Western orientation and liberalization of the economy. During the second half of 1990, the federal government prepared a blueprint for rapid liberalization of prices, wages and trade in January 1991, to be followed by rapid privatization.

The heritage of the communist Czechoslovakia was overall macroeconomic stability. The country had been a bulwark of fiscal and monetary prudence during communism (what Tošovský 1996, calls the "tradition of valuing price stability, even under central planners", p. 156) and the early transition policies confirmed this trend. Restrictive monetary and fiscal policies accompanied the start of reforms on January 1, 1991, ensuring that inflation fell rapidly after the initial one-time jump caused by price liberalization. A stable, pegged exchange rate introduced in January 1991 was undoubtedly a key nominal anchor contributing to the containment of inflation.

The policies were somewhat less successful on the "real" front, at least from the Slovak perspective. As all countries in transition, Czechoslovakia experienced a deep transition recession during the 1991-1992 period, during which output dropped significantly. This was a result of the fact that it had to deal not only with internal shocks stemming from transition, but also with the collapse of its key external markets, particularly East Germany, the Soviet Union and other CMEA countries. ${ }^{2}$ However, the effects were uneven due to different economic structure of the two republics. The Slovak economy was hit much harder than its Czech counterpart as its industrialization during the communist period made it more dependent on CMEA markets and assigned it the position of a processor of raw materials and producer of simpler manufactures. Consequently, the transition recession was more painful in Slovakia, with output dropping by more than $20 \%$ in the 1991-1992 period and unemployment exceeding 10\% (compared to the Czech Republic, where the output decline and unemployment were only half of that or less). While the divergence was to large extent inevitable given the different economic

\footnotetext{
${ }^{1}$ Due to political and economic changes, internationally comparable statistical data are not always available from the same source for the whole 1993-2007 period. Therefore, we have combined four sources of data based on the availability of datapoints for all or nearlly all the years. In some cases, this might mean that the data might be different from the Eurostat data used for international comparisons in Section II.

${ }^{2}$ CMEA was the Council of Mutual Economic Assistance, the Soviet-dominated economic and trade bloc consisting primarily of the Soviet Union and its Central and Eastern European satellites.
} 
structure of the two parts of the federation, it contributed to widespread sentiment in Slovakia that the macroeconomic policy was tailored more to the Czech than the Slovak economy.

The 1990-1992 period also witnessed swift privatization. This proceeded primarily along three fronts. The first one was the so-called restitution whereby real estate and certain other types of properties nationalized or confiscated after the 1948 Communist coup were returned to their original owners and their descendants. The second one was the small-scale privatization, whereby small retail outlets and other small-scale enterprises were sold rapidly, generally using an auction. The third and the largest one was the so-called voucher privatization used to privatize industrial and other large companies. Originally expected to foster diffuse ownership of the industry among the population, the voucher privatization ended with an overwhelming majority of shares owned by investment funds, most of which were controlled by state-owned banks. Again, this strategy was more popular in the Czech Republic than in Slovakia, where ideas of continuing state ownership and employee/management buy-outs also held strong appeal.

Economic hardship presented by this transition path to Slovakia, coupled with pressures for Slovak national emancipation as well as the position of the part of the Czech political representation that Slovakia was likely to be a liability during further reforms led to a situation where a majority of elites and population on each side declared support for the continuation of the federation, but was unable to find agreement on the precise form. This was experienced clearly both before and after the parliamentary elections of 1992, which revolved primarily around the issues of identity and economic reform. Czechoslovakia was therefore dissolved primarily because it was the only solution that both sides, in the end, were willing to accept. However, the break-up occurred in a negotiated way and with strenuous attempts by both side to minimise economic fall-out. As a result, the negative impact of independence for both sides, while significant in the short term, was minimal compared to the experience of former Yugoslavia or the Soviet Union.

\section{2 - 1998: Independence and the stalled transition}

On January 1, 1993, the independent Slovak Republic was formed. Five weeks later, on February 8, 1993, the Czecho-Slovak monetary union split and Slovakia began implementing a fully independent economic policy. Independence was originally associated with the idea of a more gradualist path of transition including continuing extensive state intervention in the economy and highly ambitious industrial policy. The loss of fiscal transfers from the Czech Republic, low credibility of the new country in international financial markets and the continuation of the economic downturn caused by the decrease in trade with the Czech Republic together meant that there was little scope for loosening macroeconomic policy and interventionist industrial policy. Instead, in its first two years, Slovakia underwent a second round of painful adjustment, associated with tax increases, limited currency devaluation and expenditure cuts. (Tóth 2000)

However, the end of 1993 marked a turning point in Slovakia's economic situation. After shrinking by 3.7\% in 1993, the real GDP grew in 1994 and 1995 close to 6\% in 
each year. The Slovak economy was able to take advantage of recovery in its main export markets of the EU and the Czech Republic and export-led growth climbed to nearly 5\% in 1994 and nearly 7\% in 1995. The recovery was based on the ability of many Slovak enterprises to supply intermediate manufacturing inputs and simple goods for OECD markets, which are both highly cyclical (OECD 1999). Of course, the cyclical upswing was supported by newly established macroeconomic stability, with inflation falling to single digits, and a lower structural fiscal deficit.

When the growth in Western Europe slowed down in 1996, the impact on the Slovak economy was as strong as the influence of the previous upturn. (Ibid.) This presented a major challenge to the government at the time. The policy reaction to the cyclical slowdown was to abandon macroeconomic stability as a key policy goal and to try to stimulate economic growth via extensive infrastructural investment and real wage increases. As a result, fiscal policy was heavily expansionary and accompanied by twin deficits. (high fiscal deficit and high deficit in the current account of the balance of payments). The fiscal deficit was in the range between 5 and 10\% of GDP during the 1996-1998 period and the current account moved from a surplus of $2 \%$ of GDP in 1995 to $-10 \%$ of GDP in 1996, where it remained until 1998.

Privatization and economic restructuring in the state-owned sector largely stopped during the 1992-1994 period when institution building and political turmoil occupied the governments. However, the Mečiar III government, which emerged from the September 1994 election to govern for the next four years, instituted a privatization strategy that was dramatically different from the previous strategy of voucher privatization. The strategy focused on selling the large industrial enterprises, especially those in the chemical, oil and paper industry as well as metallurgy that formed a backbone of the Slovak economy through their export earnings. The beneficiaries were domestic investors, with dominant shares of top managers and/or businessmen with close political ties to the government. The avowed aim was to create a domestic business/investor class that would restructure the economy and take it forward. In reality, nearly all the major enterprises were later resold to strategic foreign investors either voluntarily or due to insolvency.

At the same time, the government tried to stimulate growth in output and employment by a two-prong strategy of using state-controlled utilities to keep prices significantly below cost-recovery levels and using the state-controlled banking sector to lend to infrastructural projects as well as to keep struggling privatised enterprises afloat.

The central bank tried to provide price stability by preservation of a fixed exchange rate and low inflation, leading to only gradually appreciating real exchange rate (less than $10 \%$ between 1995 and 1998). The existence of a fixed exchange rate, a longstanding culture of low inflation and a near-freeze in regulated prices contributed to impressive disinflation. However, increasing macroeconomic imbalance required stringent monetary policy. Real ex post interest rates remained between 13 and $25 \%$ during the 1996-1998 period, as fiscal policy refused to tighten and contagion from the Asian and the Russian crisis had to be dealt with

Overall, the strategy initially did work with respect to inflation and output, but not employment. As already mentioned, inflation remained moderate - between 5 and 7\%, real GDP grew by nearly 7\% in 1996 and 4.2\% in 1997. Employment, after 
posting strong 3.6\% growth in 1996 began to decline in 1997 and would not start to grow again until 2001. However, the model was not sustainable either at the macroeconomic or microeconomic level. At the microeconomic level, privatization to domestic investors was not followed by vigorous restructuring, the ability to capture new markets or otherwise grow. State ownership and political management of the banking system meant misallocation of capital, while absence of foreign direct investment contributed to stalling of microeconomic change. Due to political problems in the 1994-1998 period, Slovakia was excluded from OECD membership, the $1^{\text {st }}$ round of NATO enlargement and it was not included among countries with which EU planned to start accession negotiations. At the macroeconomic level, the current account deficit became more and more difficult to refinance after the onset of the Asian crisis in the spring of 1997 . The combination of a very high twin deficit and extremely high real interest rates was also gradually slowing down the domestic economy. The conclusion was similar to the Czech crisis of May and June 1997: started by contagion from the Russian crisis of August 1998, domestic enterprises and households took over in speculating against the fixed exchange rate. After trying to stave off depreciation for several weeks, the central bank capitulated on October 1, 1998, and floated the currency. This was accompanied by a widespread industrial collapse, in which unemployment shot up by nearly 4 percentage points in just 1 quarter.

\section{8-2002: Cleaning up the economy}

The 1998-2002 period started with a sharp economic slowdown, rapidly rising unemployment, a full-blown macroeconomic crisis including unsustainable external deficit, a loss of exchange rate peg, and extremely high fiscal and quasi-fiscal deficit as well as a (near-)bankrupt state banking sector. By 2002, macroeconomic stability was restored together with vigorous if not extremely impressive economic growth. Banks and utilities were restructured and mostly privatized. Slovakia became member of OECD in 2000, 5-6 years after its Central European neighbors. It also joined the EU accession track from which it had been previously excluded though the process was not completed in this period. Therefore, the 1998-2002 period can be seen as a period of catching-up and cleaning up the economy. However, many structural problems underpinning the previous economic problems were not yet solved, particularly public sector efficiency problems. The wholesale change in policy was a result of a wholesale change in the government, where the 1998 election meant replacement of all government parties by the previous opposition and complete change in foreign and economic policy.

The period between late 1998 and early 2000 witnessed hard landing of the economy, with quarterly GDP growth dropping from more than 5\% in the third quarter of 1998 to negative figures in the last quarter. During most of the 1999, the growth was in the negative territory and unemployment continued to grow rapidly. By the end of 1999, the economy began to recover, albeit slowly and it is only in 2001 and 2002 that we can speak of real recovery with growth oscillating around $4 \%$ annually and the unemployment declining.

Restrictive measures taken by the Dzurinda I government to resolve the external and fiscal imbalance contributed to the slowdown. After the parliamentary elections of 
1998, a new policy of stabilization and rapid structural reforms began, relieving imbalances at the expense of increased inflation and unemployment as well as slower GDP growth. A decrease in the fiscal deficit and in household consumption produced a temporary and substantial reduction in the external imbalance during 1999 and 2000, while core inflation remained stable. After years of moderate inflation, it increased steeply during 1999 and 2000, particularly between July 1999 and July 2000 when it was above 14\%. This was caused primarily by high increases in regulated prices, increases in indirect taxes, the reintroduction of an import surcharge and the depreciation of the Slovak crown. However, once the one-time shocks related to these factors disappeared, inflation fell substantially and returned to previous levels. A dramatic decrease in government demand for domestic savings and decrease in bank interest in other than risk-free lending activities accompanied economic slowdown. This was caused by a decrease in the general government deficit as well as by the shifting of some of its financing to foreign markets and by bank restructuring. All of this resulted in a steep fall in interest rates without a corresponding steep increase in lending.

The 1998-2002 period was also a period of vigorous industrial restructuring following the collapse of the previous model. Large state-owned banks, technically insolvent by 1998, were consolidated and privatized, together with many utilities. The corporate income tax was cut from $40 \%$ to $25 \%$ in several steps. The government embarked on improvements in the legal environment, with overhauls of bankruptcy and corporate governance. On one hand, this meant a much lower cost of capital for profitable and growing businesses, but it also meant loss of financing based on political decisionmaking and significant increase in cost for resource-intensive enterprises. The government took vigorous steps to attract foreign capital, both via privatization of banks and network industries, but also through greenfield industrial projects. The domestic owners of the country's industrial base in many cases resold it to strategic foreign investors. The reforms also brought significant decrease in corruption in the private sector and its dealings with the public counterpart.

The Dzurinda I government also attempted several ambitious structural reforms to improve efficiency of public spending and sustainability of the public finance. Foremost among these were the pension and education reforms. However, due to political disagreements between the government parties, the final versions were often either not approved or approved in a form, which was not likely to achieve the required result. In the pension area, the law overhauling the $1^{\text {st }}$ pillar was passed, but never implemented even though it was quite similar to the law later passed by the Dzurinda II government. The Ministry of Labor, Social Affairs and Family proposed an introduction of the $2^{\text {nd }}$ pension pillar, but it was never approved, as it was very late in the government term and with a relatively small compulsory pillar. In the education area, the record was better with a far-reaching Higher Education Act passed in 2002 whose principles have been respected by two subsequent governments (even though the consensus was achieved by avoiding the issue of tuition). At the same time, the Primary and Secondary Education Financing Act officially aimed at restructuring the excessive school network did not achieve its objective because of the conflict between the objective and the incentives offered by the actual law. In health care, the record was the worst, with public confidence in the system reaching record lows and indebtedness reaching record highs. The perceptions were worsened by the iconic case of President Schuster saved by the Austrian hospital after nearly dying in 
Slovakia.

\section{2-2006: Completing the transition - structural reform and EU accession}

It is perilous to pronounce an "end to transition", however, the 2002-2006 period is the best candidate to mark it. A combination of structural reforms and the EU accession did not mean "the end of history" in Slovakia, but they meant that the country's problems after 2006 are now familiar to analysts of any countries at the lower rungs of the developed world (e.g. Chile, Brazil, Portugal) rather than relating specifically to the postcommunist experience. Even though the 2002 election confirmed a high level of continuity in economic policy, there is a general tendency to treat the two periods separately when describing developments in policy as well as the economy. The reason is the perceived rupture with previous policies. However, one should not overstate the point. The economic picture improved continuously from the low point in late 1999/early 2000 on. Also, the Dzurinda II government continued and built upon the privatization and deregulation policies of its predecessor in areas such as banking and utilities as well as the business environment. On the other hand, there are two key differences.

One is the much higher level of growth. The average growth under the Dzurinda II government reached $6 \%$, accelerating from less than $5 \%$ at the beginning to $9 \%$ by the end. The growth was driven primarily by massive FDI inflows, particularly in the automobile, electronics and engineering industries. The FDI inflows and resulting jumps in the productive capacity, together with inflows of the EU funding after 2004, fueled construction and household consumption boom. However, the key ingredient that makes the difference between the two governments is the attention paid to fiscal consolidation and far-reaching structural reforms aimed at both short-term improvements in the fiscal deficit and assuring long-term fiscal sustainability. For better or worse, the structurally based fiscal consolidation, wrapped in the objective of fulfilling the Maastricht criteria for euro zone entry by 2006, became the guiding mantra of economic policy-making. As a result, Slovakia entered the ERM-II mechanism in November 2005 to prepare itself for the euro adoption in 2009. The pace of fiscal consolidation during the $2002-2003$ period was radical. From $8.2 \%$ of GDP in 2002, the budget deficit dropped to $2.7 \%$ of GDP in 2003. It is interesting to note that the fiscal consolidation has been essentially non-existent ever since. This leads to a more nuanced view of the following 2004 structural reform package. It was not made necessary by short-term fiscal exigencies - these had been largely solved through budget cuts of the 2003 budget. Rather, the reform package of 2004 was intended to increase efficiency and effectiveness of a given level of public spending and the long-term sustainability of the public sector and thus to improve the long-term growth prospects of Slovakia. Four key parts of the package will be presented here.

The first one is the tax policy. Slovakia was among several Central and Eastern European states that implemented the concept of flat tax, but the Slovak example became one of the most referred to, partially because it seemed to capture the liberal spirit of the overall policy efforts of the government, but also because it was one of the most thorough implementations of the concept. The thoroughness was not only in the fact that tax rates for both corporate and income taxes as well as the VAT rate were unified at $19 \%$, which was unique in itself, but also in the wholesale 
simplification of the tax code that accompanied it. The flat tax had important, but non-obvious redistributive impact. First of all, because of the increase in the personal tax deduction and introduction of refundable child tax credits, the working poor benefited from the change, particularly if they had several children. At the same time, high-income individuals benefited even more, while those around average income saw the smallest benefits. Since the lower rate of VAT was increased significantly as a part of the tax rate unification and excise taxes were also raised, this had a regressive effect, particularly pronounced for those poorer households with substantial alcohol and tobacco consumption. For pensioners, much of the negative impact was cushioned by high nominal increase in pensions and liberalization of work, but for social assistance recipients, this was not so. Ultimately, the flat tax needs to be understood in political as well as economic terms. It was an attempt to package pro-investment and pro-employment policy in simple and politically attractive terms. In this respect, it succeeded greatly, particularly with foreign investors despite the continuing complexity of tax administration (as revealed, for example, by continuing very bad rankings of Slovakia in the World Bank Doing Business reports).

The second area of interest is the social policy. In social policy, the government focused on employment growth and pension reform. Policy-makers believed that, in the presence of rapid economic growth, "incentives posed by social policy and flexibility of the labor market are also important" for employment. (MoLSAF 2003a, p. 1) According to this view, the labor market suffered from "rigidity of the labor market, extremely high labor taxation, a poverty trap posed by the current social policy" (ibid.) and badly organized active labor market policies. Even though the policy response to the diagnosis was comprehensive and complex, it can be simplied to "making work pay". With regard to pensions, the government's view was that: "The main problem of the current system for funding pensions in Slovakia is the domination of the public pay-as-you-go pillar. This system is unsustainable in its current form." (MoLSAF 2003b, p. 1) This led to restructuring of the 1st (pay-asyou-go) pension pillar, with the following key changes:

- increase in the pension age from 60 for men and 53-57 for women to 62 years of age

- introduction of more actuarial approach to the pension calculation with pensions closely reflecting contributions at the individual level

- review of disability rules and existing disability pensions

Of course, these massive changes were and continue to be highly controversial. At the same time, opinion polls showed that they were not among the most negatively perceived ones (education and health care were significantly more unpopular) and the pension reform and family benefit reforms were even fairly popular.

Due to both public and elite frustration with the state of healthcare, there was initially great receptiveness to the idea of comprehensive healthcare reform. By 2006, polling showed that more than $70 \%$ had negative views of the healthcare reform as implemented. What accounts for the turnaround and does it reflect only unpopularity of necessary changes or genuine problems in the design and execution of the reform? The healthcare reform was a two-stage process. The first stage, undertaken primarily in 2003, focused on slowing down expenditure growth by one-time measures introduction of small fees for doctor visit, hospital stays and drugs as well as changes 
in drug reimbursements for drug companies. The second stage, originally supposed to start in 2004 with the other reforms, but ultimately delayed until 2005, brought a fundamental overhaul of the healthcare system. All hospitals were to be corporatized and restructured (and some even privatized), insurance companies were to become profit-seeking health management organizations, insurers and providers were to freely negotiate prices and quantities, the government was supposed to clearly determine the extent of the free healthcare package and the co-payments for diagnoses not in it and a strict hard budget constraint was to be introduced for all actors involved.

It is difficult to evaluate the healthcare reform because it was never fully carried out. First of all, due to its late passage, it had to be substantially modified as the government lacked a clear majority by this time. Secondly, some of the most important measures that were passed were not implemented by the time the new government took over and were subsequently cancelled. This concerned primarily the corporatization, which was only half-finished and a clear definition of the healthcare package. Additionally, healthcare even less than other sectors offers a possibility of one reform "solving" the problems once and for all as the changing technology and demographics tend to create recurring financial challenges. Nonetheless, by 2006, it was difficult to observe major changes in how healthcare operates in Slovakia with the exception of financial stabilization, which however is no small achievement

The last major area of interest was education. The experience was the reverse of the 1998-2002 period: significant progress with restructuring of the primary and secondary education network, much less so in higher education. In primary and secondary education, 2004 saw transfer of ownership of primary and secondary schools to municipalities and regions together with a new funding formula based strongly on the number of students. Together, these two changes created strong incentives for savings via school closure and resulting decrease in staff numbers, which duly followed. As the pupil numbers were decreasing continuously and significantly (by 38\% for Grades 1-4 and 22\% for Grades 5-9 between 1989 and 2006), there was a consensus on the need to restructure the network though there were disagreements on the speed and extent to which it should happen. At the same time, the public funding grew substantially in real terms, allowing for sustained increase in salaries. In higher education, the 2002-2006 period was the one when the impact of the 2002 Higher Education Act played itself out. Since the act introduced a funding system relying on the number of students as the primary criterion and was accompanied by substantial though gradual increase in public funding, enrollment in Slovak universities exploded from 140 thousand in 2002 to more than 200 thousand in 2006. However, this development was overshadowed by two others - rising concern about the quality and the unsuccessful attempts by the government to introduce tuition fees.

Most of the text for this period is devoted to fiscal and structural reform issues due to their prominence in the economic agenda at the time. However, other areas should not be completely ignored. Regarding privatization, FDI and industrial policy, there was much continuity with the Dzurinda I government. The government continued in privatization of utilities, with the privatization of the electricity-generating company being the largest sale of the period. It also expanded restructuring and privatization in the transport area (Košice Airport, finalization of bus company privatization) even though some of these efforts were cancelled by the subsequent government 
(Bratislava Airport, cargo railway company). FDI, particularly for new manufacturing productivity, accelerated dramatically, with two new car plants - PSA Citroen and KIA - becoming both magnets for investment by their suppliers and icons of the change in Slovak economic fortune.

\section{6- : Distributing the fruits of growth - rupture or continuity?}

The 2006 election meant a wholesale change in the composition of the government, with all government parties moving to the opposition and vice versa. Unlike in 1998, the last time this happened, the rupture in economic policy and outcomes was modest (and more modest than expected by most observers). Under the new government, economic growth accelerated to (briefly) reach $10 \%$ and kept Slovakia among the fastest growing EU countries during the whole 2006-2008 period. Employment growth continued steadily, with macroeconomic stability retained and accompanied by low inflation. At the same time, the fiscal policy remained slightly pro-cyclical and did not consolidate further (the fiscal deficit remained around $2 \%$ of GDP during the whole 2003-2008 period with the exception of 2006 when the incoming government increased it on a one-time basis to pay for some of the election promises).

From an economic point of view, three topics dominated the public debate between 2006 and 2008:

- the social "face" of the Slovak economy

- fate of the structural reforms undertaken by the previous government

- $\quad$ the planned adoption of euro in January 2009

With regard to its social "face", the new government has pursued a strategy of vigorous protection of households against negative shocks combined with selective new initiatives. After the experience of the 1998-2006 period when utility prices rose significantly to bring them to cost-recovery level, nominal stability or small price increases have great popular appeal. This pillar of the government strategy is being made increasingly more difficult by the fact that global energy and food prices continue to rise. The selective new initiatives contained Christmas bonuses for pensioners, increase in the one-time payment to parents of the first child, introducing lower VAT for drugs and books and abolition of patient fees introduced previously. All of the measures have been highly popular and, despite their modest fiscal and redistributive impact, politically effective. The government aims to continue with this strategy in 2009 to coincide with euro adoption.

When the Fico government came to power, the pre-election rhetoric led many observers to believe that a wholesale reversal of policies introduced by the previous government would ensue. That this has not happened has been of the most often remarked upon features of the 2006-2008 period. However, from a political view this not surprising, as the polling in 2005 and early 2006 consistently showed that a majority of more than $70 \%$ the population desired to "improve" rather than "abolish" reforms. However, the view that "nothing has changed" is also highly misleading. It was already mentioned that the government reversed important planks of the healthcare reform and it also sought to push out private insurers by forbidding them to withdraw retained profits. Therefore, any notion of continuity in healthcare is exaggerated. In social policy, the government also partially reversed major policy 
steps of its predecessor, particularly concerning the labor market (Labor Code, collective bargaining) and pensions (making the $2^{\text {nd }}$ pillar voluntary rather than mandatory for new labor market entrants). In education, the change has been less pronounced, but paradoxically the government has been able to introduce tuition fees though only for part-time students, a policy step rejected by the previous government as discriminatory.

The biggest rupture has been on the privatization front where the new government has not only sharply criticized the previous one for sales of utilities, it also cancelled all incomplete transactions and blocked any further privatization. Instead, the government turned to exploration of public-private partnership and public investment. The PPP is particularly salient for road infrastructure where major routes in the network are expected to be completed using the method as a part of the government bid to accelerate construction of the Bratislava-Košice and Bratislava-Banská Bystrica corridors.

A key influence on the government policy has been the planned euro adoption in 2009. The government decision to stick to the commitment made by its predecessor came in the first month of the government term and coincided with depreciation of the currency following the market uncertainty about the policy and fiscal strategy of the new government.

\section{SECTION II: Special topics in Slovakia's transition}

In this section, we take a closer look at three special topics in the Slovakia's transition from a comparative perspective. This enables us both to see developments in some of the key issue in transition over time and to see where Slovakia has come to diverge (or not) from its neighbors. We look at the growth, size of the state and equity, then at labor market outcomes and lastly at industrial policy, privatization and FDI. Slovakia is compared with the average of its natural peer group - Central European Visegrad-4 group consisting of itself, the Czech Republic, Hungary and Poland.

\section{Growth, state and equity}

In this subsection, the developments in economic growth, size of the state and equity are explored as well as their mutual relationship. The data show that Slovakia has been able to consistently outperform its Central European peers in growth performance since 2004, leading to rapid catch-up in the standards of living. The growth spurt was preceded inter alia by significant reduction in the size of the state both on the revenue and expenditure side, with much of the expenditure consolidation driven by reduction of social protection expenditure. However, smaller state did not lead to subpar performance in equity. Instead, a combination of low historical inequality, good labor market performance and efficient transfer system mean that the small state is accompanied by relatively high level of equity. Therefore, Slovakia has not exhibited growth-equity trade-off during the last decade.

Let us start with a brief analysis of the Slovak growth performance. As shown in Chart II.1, between mid-1990s and early 2000s, Slovakia was growing in line with its 
Central European peers though the absolute levels of income were lagging somewhat behind. The difference between Slovakia and the V4 average in GDP per capita expressed as the percentage of the EU-27 average ranged from 4 to 6 percentage points between 1995 and 2003 without convergence.

Chart II.1: GDP per capita in Slovakia vs V4 average as \% of the EU-27 average, 1995-2007

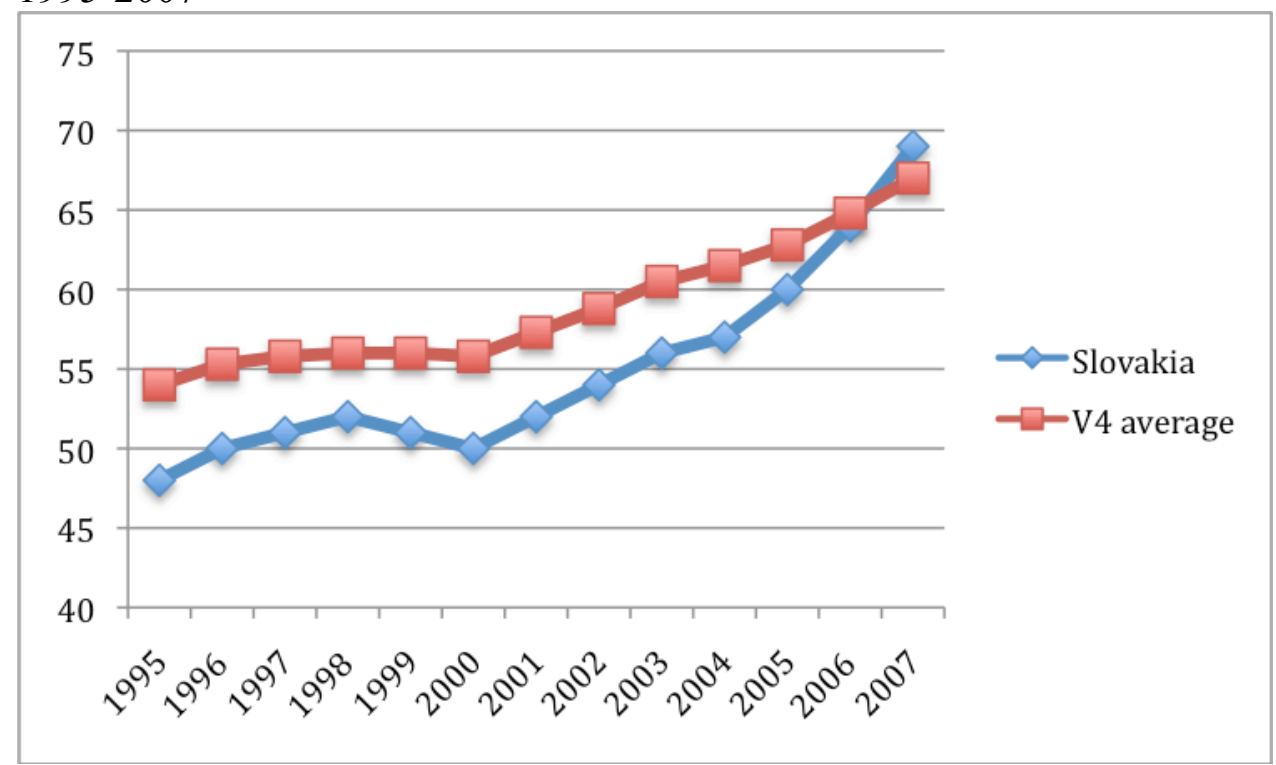

Source: Eurostat

Since 2004, the growth performance changed significantly. In just 4 years, Slovakia not only caught up with its peers, but (by 2007) was ahead by 2 percentage points. By 2009, the gap should further widen to 3.2 percentage points according to the Eurostat forecasts. This shows that the Slovak growth performance can be attributed neither to common influences (such as the EU accession), nor to cyclical factors. Obviously, the Slovak potential growth increased substantially around the 2003-2004 period. A variety of potential factors can be discerned:

- delayed effects of structural improvements implemented during the 1998-2002 period (bank restructuring, business climate improvements) and discussed in Section I

- improvement in public finances and decrease in the size of the state as discussed below in this section

- structural reforms improving the efficiency and effectiveness of public expenditure (as also discussed in Section I, but also in other parts of this section)

Changes in the size of state obviously played a role in the growth performances, as they were crucial both to lower taxation and macroeconomic stability. Chart II.2 compares the evolution of the fiscal revenue in Slovakia with the average of the Visegrad group. As we can see, Slovakia was very close to the average in mid-1990s and the decline in its revenue-generating capacities closely followed that of its neighbors between 1995 and 2000. However, since 2000 the V4 average has remained steady around $40 \%$ of GDP whereas Slovakia's fiscal revenue continued to decline to around $35 \%$ of GDP, creating a gap of 5 percentage points. The fact that this gap opened between 2000 and 2004 shows that there was more continuity than difference 
in the overall tax and revenue policy between the two Dzurinda governments.

Chart II.2: Public revenue as \% of GDP in Slovakia vs. V4 average, 1995-2007

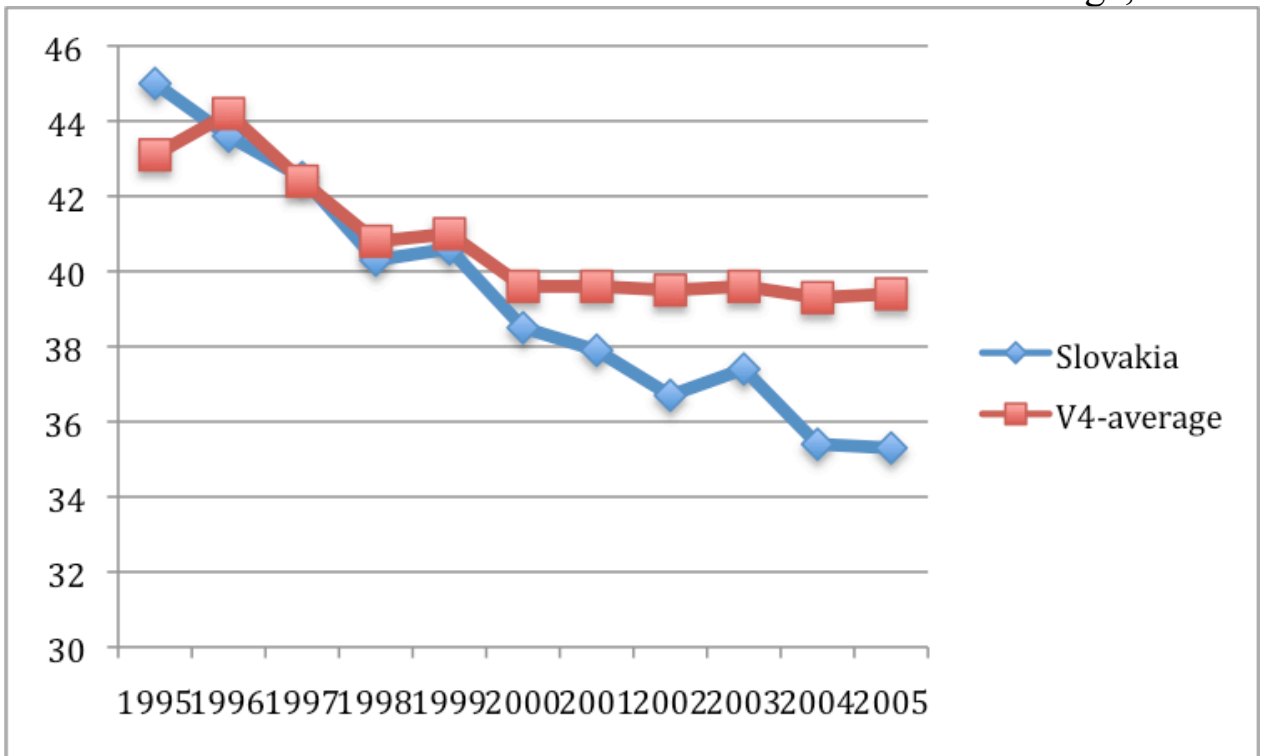

Source: Eurostat

Equally important was the change in the structure of the revenue. As Chart II.3 shows, all three key sources of revenue - indirect taxes, direct taxes and social security contributions - declined during the 1995-2007 period. However, the direct taxes declined the most in relative terms - from more than $10 \%$ of GDP to $6 \%$, while indirect taxes stabilized after 1999. Therefore, the continuing decline in the revenue after 2000 can be primarily attributed to decrease in direct taxes resulting primarily from decreasing tax rates for both corporate and personal income.

Chart II.3: Sources of public revenue in Slovakia as \% of GDP, 1995-2007

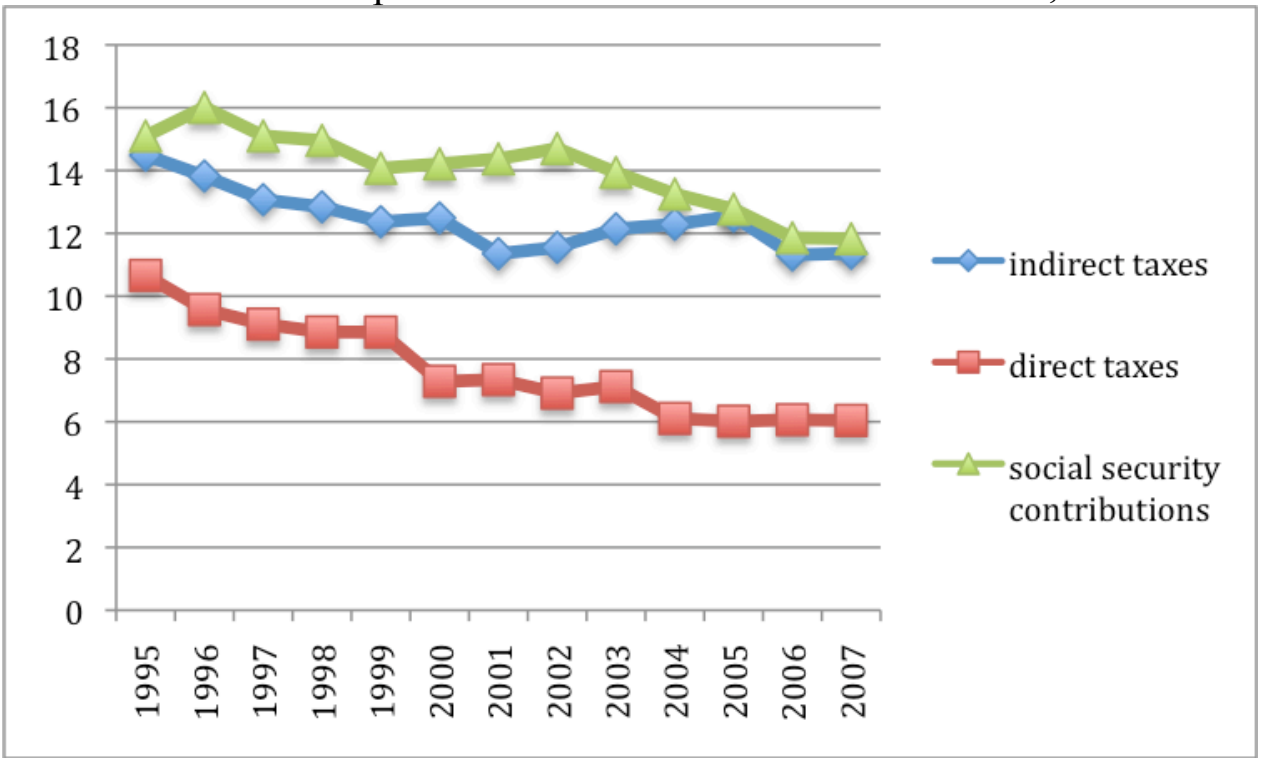

Source: Eurostat

The developments were even more dramatic on the expenditure side because Slovakia actually exceeded the V4 average in the second half of 1990s, before undershooting it by as much as $6 \%$ of GDP by 2006 and 2007. This is shown in Chart II.4. At the same 
time, long-term sustainability of the public finance improved. The EU evaluation has put Slovakia in the group with medium-size risks in terms of public finance sustainability (compared to high risk for the Czech Republic and Hungary and low risk for Poland). (European Commission 2006, p. 86) According to this assessment, Slovakia has dealt relatively successfully with the long-term impact of ageing, but it still needed to consolidate its public finance to provide strong foundations to withstand (even limited) impact of ageing in the coming decades.

Chart II.4: Public expenditure as \% of GDP in Slovakia and the V4 average, 19952007

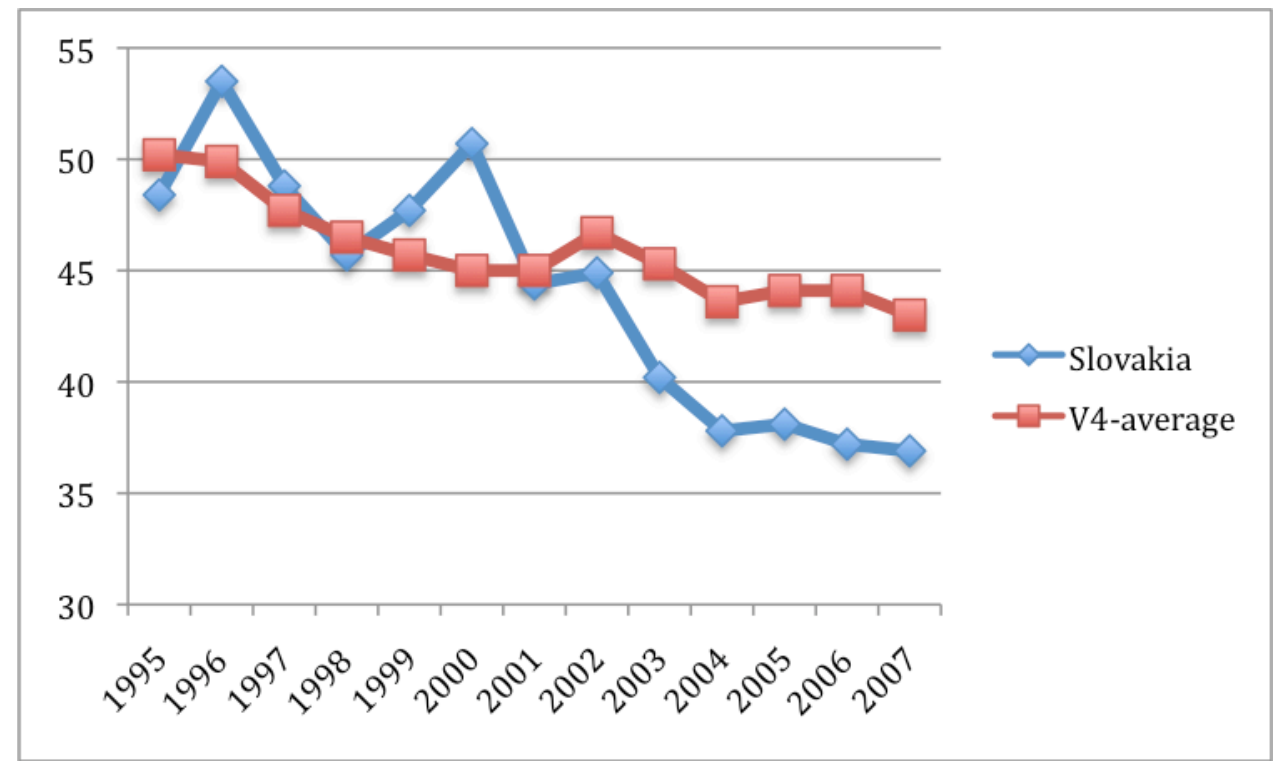

Source: Eurostat

The expenditure consolidation was spread throughout the public sector. However, one area stands out as bearing the brunt of the adjustment - social protection. As we can see in Table II.1, Slovakia has cut social protection expenditure during the 1999-2005 period from $20 \%$ of GDP in 1999 to $16.9 \%$ in 2005 , with available data indicating further though mild decrease in the 2006-2008 period, for which the comparable data for other countries are not yet officially available. In this, it has been different from every other Visegrad country, which have all maintained approximately the same level of social protection expenditure.

Table II.1: Social protection expenditure, 1999-2005

\begin{tabular}{|l|l|l|l|l|l|l|l|}
\hline & 1999 & 2000 & 2001 & 2002 & 2003 & 2004 & 2005 \\
\hline $\begin{array}{l}\text { Czech } \\
\text { Republic }\end{array}$ & 19.2 & 19.5 & 19.5 & 20.2 & 20.2 & 19.3 & 19.1 \\
\hline Hungary & 20.7 & 19.3 & 19.3 & 20.4 & 21.1 & 20.7 & 21.9 \\
\hline Poland & n.a. & 19.7 & 21 & 21.1 & 21 & 20.1 & 19.6 \\
\hline Slovakia & 20 & 19.3 & 18.9 & 19 & 18.2 & 17.3 & 16.9 \\
\hline V4 average & 20 & 19.5 & 19.7 & 20.2 & 20.1 & 19.4 & 19.4 \\
\hline
\end{tabular}




\begin{tabular}{|l|l|l|l|l|l|l|l|}
\hline difference & 0 & -0.2 & -0.8 & -1.2 & -1.9 & -2.1 & -2.5 \\
\hline
\end{tabular}

Source: Eurostat

Based on the social protection expenditure data, one would expect Slovakia to demonstrate much more pronounced inequalities than its neighbors. However, two widely used EU indicators - risk-of-poverty and income inequality - show that this has not been the case. The risk of poverty refers to the percentage of the population that has a total income of less than $60 \%$ of the national median. Its value is in showing what percentage of the population is financially lagging far behind the mainstream population. On this measure, Slovakia has much lower inequality than Poland and Hungary and only slightly higher than the Czech Republic. The result is even more impressivebecause it has improved recently, from $13.3 \%$ for 2004 to $10.7 \%$ for 2006 .

Table II.2: Risk of poverty - percentage of the population with income less than $60 \%$ of the national median, 2005

\begin{tabular}{|l|l|}
\hline Country & Risk-of-poverty rate \\
\hline Czech Republic & 10 \\
\hline Hungary & 16 \\
\hline Poland & 19 \\
\hline Slovakia & 12 \\
\hline V4 average & 14.25 \\
\hline
\end{tabular}

Source: Eurostat

Note: Eurostat shows these data as 2006 data, but the reference period for which they were collected was 2005 , so it is shown here as 2005 data

A similar picture is provided by the inequality measure that looks at the ratio of incomes of individuals at the $80^{\text {th }}$ percentile of the income scale to incomes of those at the $20^{\text {th }}$ percentile. The puzzle is explained somewhat by looking at the data before and after social transfers are counted in. Slovakia produces fewer inequalities than most other EU countries and then uses efficient antipoverty measures, particularly in terms of the pension system.

Table II.3: risk of poverty before and after transfers, 2005

\begin{tabular}{|l|l|l|l|}
\hline & before transfers & after pensions & $\begin{array}{l}\text { after all social } \\
\text { transfers }\end{array}$ \\
\hline Czech Republic & 39 & 22 & 10 \\
\hline Hungary & 49 & 30 & 16 \\
\hline Poland & 49 & 29 & 19 \\
\hline Slovakia & 39 & 20 & 12 \\
\hline
\end{tabular}




\begin{tabular}{|l|l|l|l|}
\hline V4 average & 44 & 25.3 & 14.3 \\
\hline
\end{tabular}

Source: Eurostat

\section{Labor market outcomes}

Labor market, particularly high unemployment, has presented one of the biggest challenges for Slovakia in its transition to the labor market. Shortly after the beginning of transition, unemployment exceeded $10 \%$ and remained in double digits ever since (though it is expected to drop below 10\% during late 2008). As shown in Chart II.5, between 2000 and 2004, unemployment on several occasions reached or came close to $20 \%$. Slovakia has thus generally had one of the highest unemployment rates among advanced transition countries, rivaled only by Poland. However, since 2004 , it has dropped from more than $18 \%$ to $10 \%$ based on strong and sustained growth of employment. Even though it is difficult to disentangle causality, there are indications that the labor market reforms introduced in 2004 have contributed to the outcome.

Chart II.5: Unemployment rate in Slovakia vs V4 average, 1998-2007

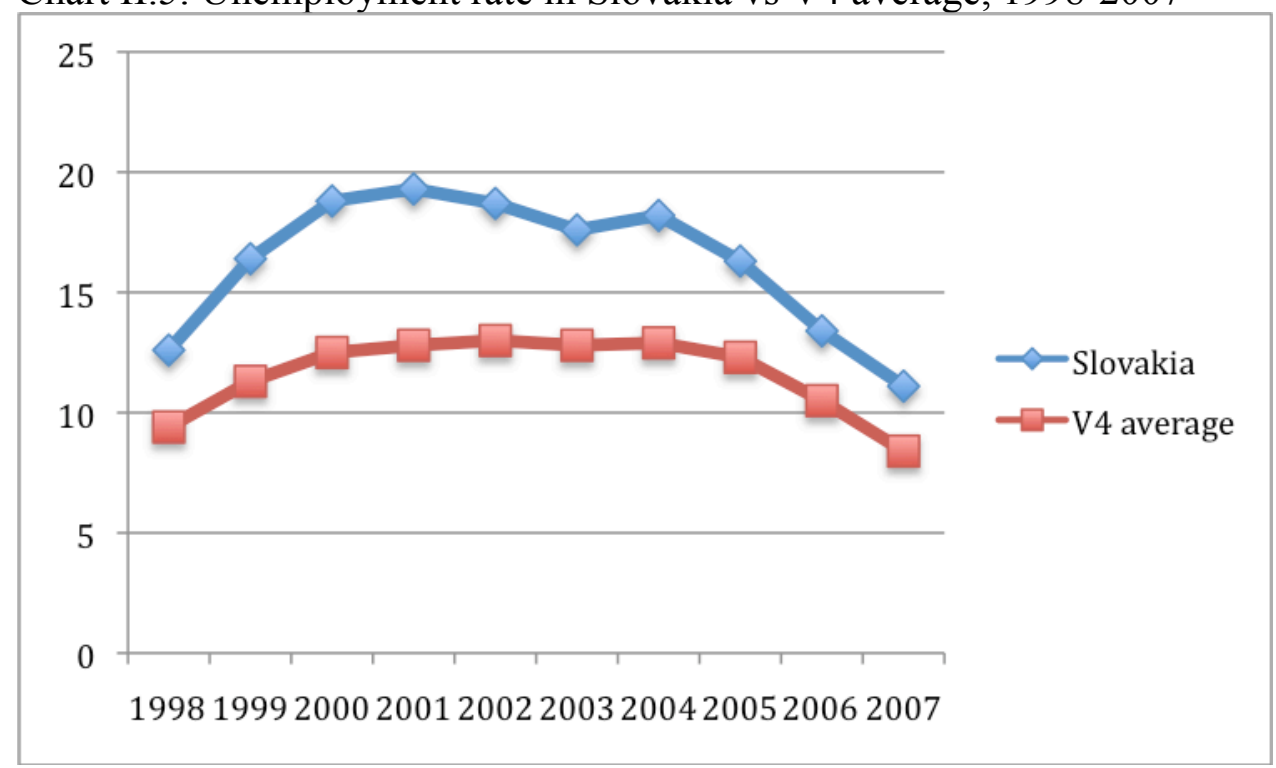

Source: Eurostat

The very high levels of unemployment did not reflect unusually low employment, at least compared to the peer group - as shown in Chart II.6. Rather, the difference in unemployment was related more to unusually high levels of economic activity. Slovakia has had participation rates, which were consistently 2-3 percentage points above the Central European average.

Chart II.6: Employment rate among the population aged 15-64 in Slovakia vs V4 average, 1998-2007 


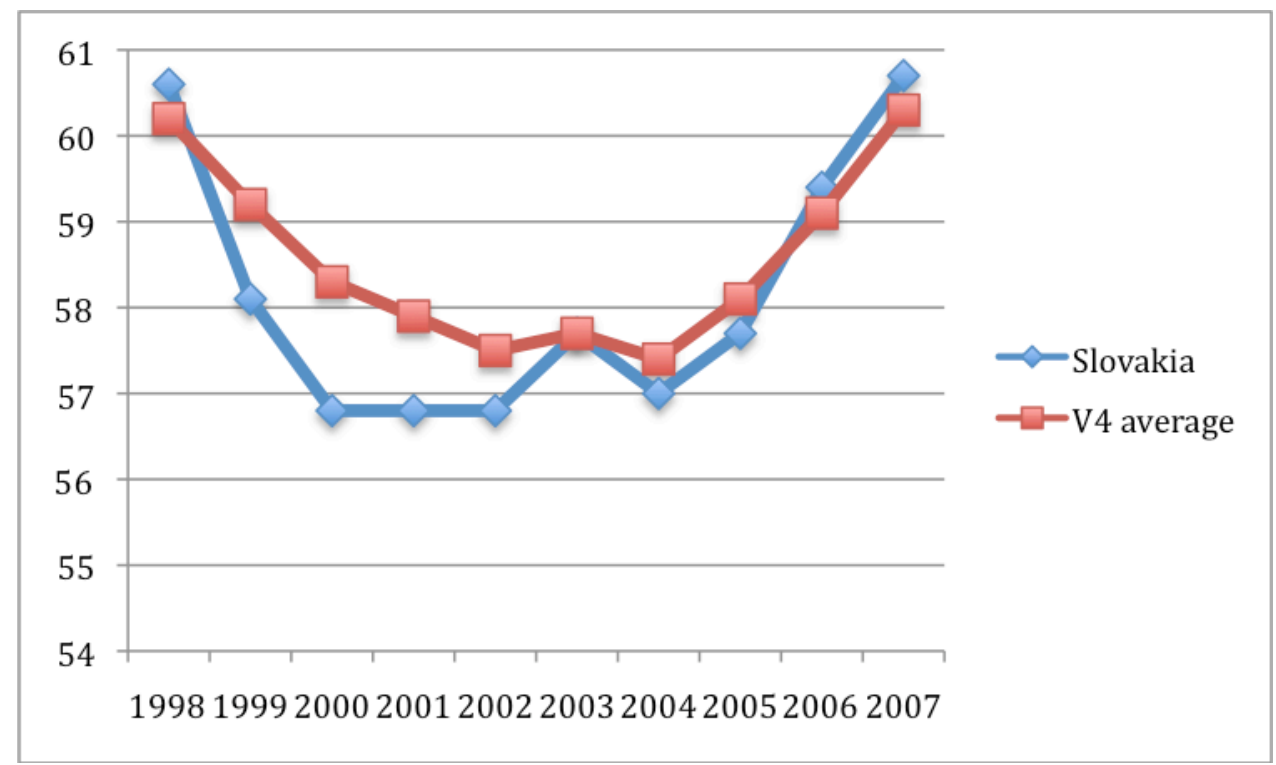

Source: Eurostat

As analyzed in section I, one of the key objectives of the 2004 reform package was to achieve rapid growth in employment and corresponding decline in unemployment. As a part of this package, the minimum income guarantee scheme, the income tax and unemployment insurance and sickness benefit, benefits for families with children, the Labor Code and labor market institutions (collective bargaining), active labor market policy and the government bureaucracy in the area of employment and social policy all underwent radical overhaul. The beginning of 2004, when the reform package was implemented, corresponds to the lowest point in terms of employment during the Dzurinda II government. Since then, employment growth has been strong, between 2 and 4\% on an annual basis (discounting seasonal effects). Between 2004 and 2008, Slovakia saw the strongest and the only sustained period of employment growth during the transition. Unemployment levels also reached the lowest levels recorded during the transition by early 2008. Therefore, there is no doubt that Slovakia experienced much improved labor market outcomes. It is not possible to ascertain the precise contribution of the labor market reform. However there are indications that they have played a role.

First of all, while the EU accession in May 2004 and the consequent labor market integration had positive labor market effects, this can explain only part of the Slovak employment growth. Before the accession, the Slovak employment rate lagged behind the Central European average. By 2007, it was ahead of it. Secondly, previously even periods of significant economic growth were not sufficient for sustained employment growth. Indeed, in 2003 employment stopped growing and began to decline when the economic growth was already reaching 5\%. Thirdly, the labor market reforms had measurable impact on incentives, sharply improving rewards of work. This is shown in Table II.4, which depicts the so-called unemployment and poverty traps in Slovakia and the Central Europe as a whole prior to the labor market reform package and after it. Poverty and unemployment traps measure tax rate on low wage earners by marginal effective tax rates on employment incomes. Lower value indicates smaller disincentives to work. We can see that for all three groups where the indicator is calculated by Eurostat, Slovakia experience substantial improvement between 2003 and 2004, putting it significantly ahead of the V4 average. 
Table II.4: Unemployment and poverty traps in Slovakia vs V4 average, 2003 vs 2004

\begin{tabular}{|c|c|c|c|c|c|c|}
\hline & \multicolumn{2}{|c|}{$\begin{array}{l}\text { Single person without } \\
\text { children }\end{array}$} & \multicolumn{2}{|c|}{$\begin{array}{l}\text { Single person without } \\
\text { children, } 33 \% \text { of average } \\
\text { wage }\end{array}$} & \multicolumn{2}{|c|}{$\begin{array}{l}\text { One-earner married } \\
\text { couple, at } 33 \% \text { of average } \\
\text { wage, with two children }\end{array}$} \\
\hline & 2003 & 2004 & 2003 & 2004 & 2003 & 2004 \\
\hline Slovakia & 70 & 43 & 30 & 23 & 100 & 34 \\
\hline V4 average & 70.75 & 64 & 42 & 40.5 & 71.25 & 56 \\
\hline
\end{tabular}

Source: Eurostat

\section{Industrial policy, privatization and FDI}

Slovakia is an example of two very sharp shifts in privatization and industrial policies. One occurred in mid-1990s, when voucher privatization and liberal industrial policy was replaced by privatization to managers and domestic business groups and an industrial policy of keeping selective enterprises afloat through state-owned banks, which also financed privatization. The second occurred at the end of 1990s, when this model was replaced by a model of bank privatization, (re)privatization not only of manufacturing, but also of utilities to foreign strategic investors, explicit preference for FDI in major manufacturing greenfield sites as well as strictly horizontal approach towards investment and business development (lower taxation, better regulatory environment). The change of government in 2006 meant a stop to privatization, but the remaining stock of government business activities is relatively minor, so the practical difference is not paradigmatic. In the interest of brevity, we shall trace influences of the policy shifts through four indicators - competitiveness as proxied by industrial labor productivity, decline in state ownership of banks and of the economy as a whole and foreign direct investment.

The first indicator concerns change in industrial labor productivity. As we can see in Chart II.7, until 2000, Slovakia consistently lacked in productivity growth compared to the V4 average, while since 2000 (with the exception of one year), the productivity growth has been equal or higher than the V4 average.

Chart II.7: Change in labor productivity in industry (in per cent), Slovakia vs. V4 average, 1990-2006 


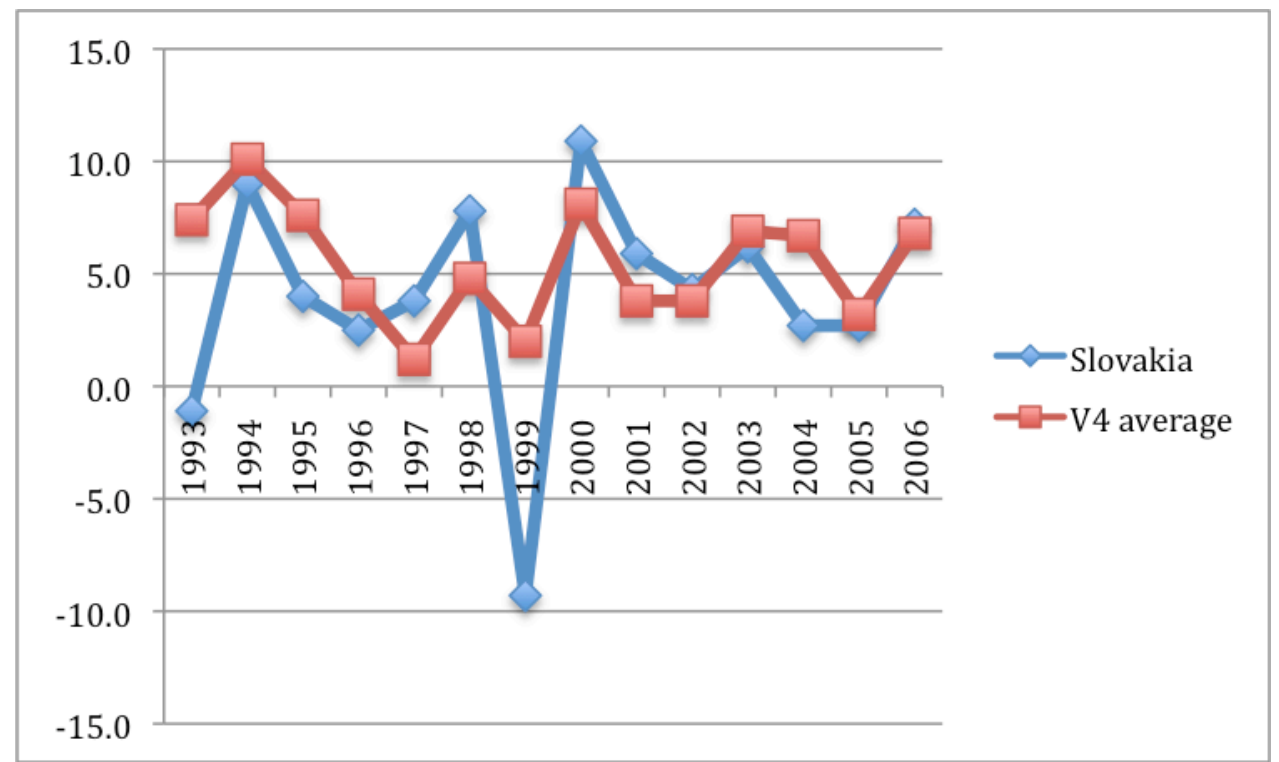

Source: EBRD

Secondly, we look at asset share of state-owned banks in Slovakia compared to the other Visegrad countries. What we see in Chart II.8 is that Slovakia preserved a steady share of state-owned banks in the banking market of more than $50 \%$ throughout the second half of 1990 while the regional average continued to steadily drop. However, once the restructuring and privatization of state-owned banks went ahead, Slovakia dropped from more than $50 \%$ essentially to $0 \%$ within one year. Again, this illustrates the policy shift made after the 1998 election.

Chart II.8: Asset share of state-owned banks (in per cent), Slovakia vs. V4 average, $1993-2006$

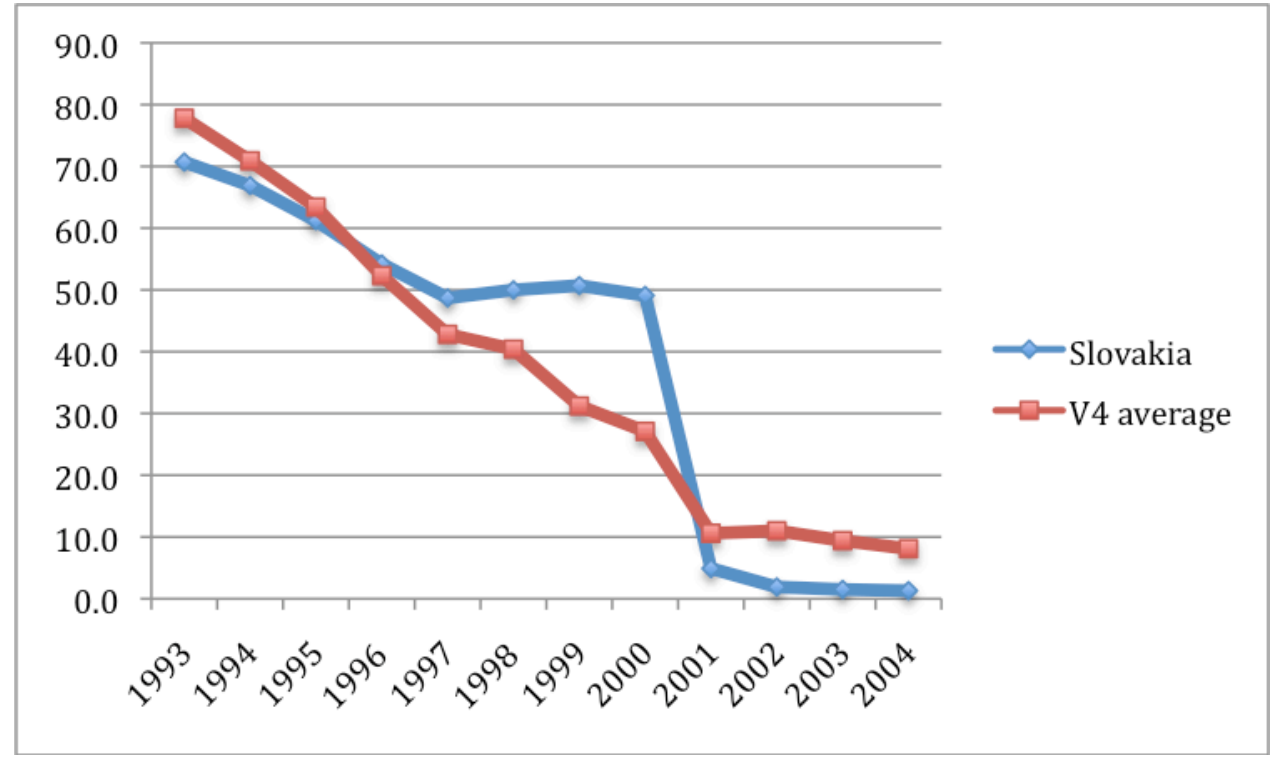

Source: EBRD

The third indicator concerns cumulative privatization revenues. The indicator was 
chosen to show the speed and extent of privatization. ${ }^{3}$ What it shows (in Chart II.9), is that privatization revenues in Slovakia lagged slightly behind the Visegrad average during the second half of 1990s. As we know that the privatization strategy at the time was biased towards low-priced direct sales to domestic buyers, that suggests that Slovakia never lagged substantially behind its neighbors in the pace of privatization, just in the amount of money it was able to extract from it. On the other hand, the revenue sharply increased between 1999 and 2002, when the principal banking and utility sales took place (with the sale of the gas pipeline and distribution company SPP accounting for the biggest share). Since 2002, the privatization in Slovakia has slowed down significantly. This strengthens the point made in the previous section that the main privatization occurred between 1999 and 2002 and that the post-2006 formal privatization ban, while important in individual cases, can be expected to have limited influence macroeconomically. In other words, Slovakia essentially ran out of things to privatize by 2002 while some of its neighbors did not move so fast and are, therefore, still catching up.

Chart II.9: Privatization revenues (cumulative, in per cent of GDP), Slovakia vs. V4 average, 1993-2006

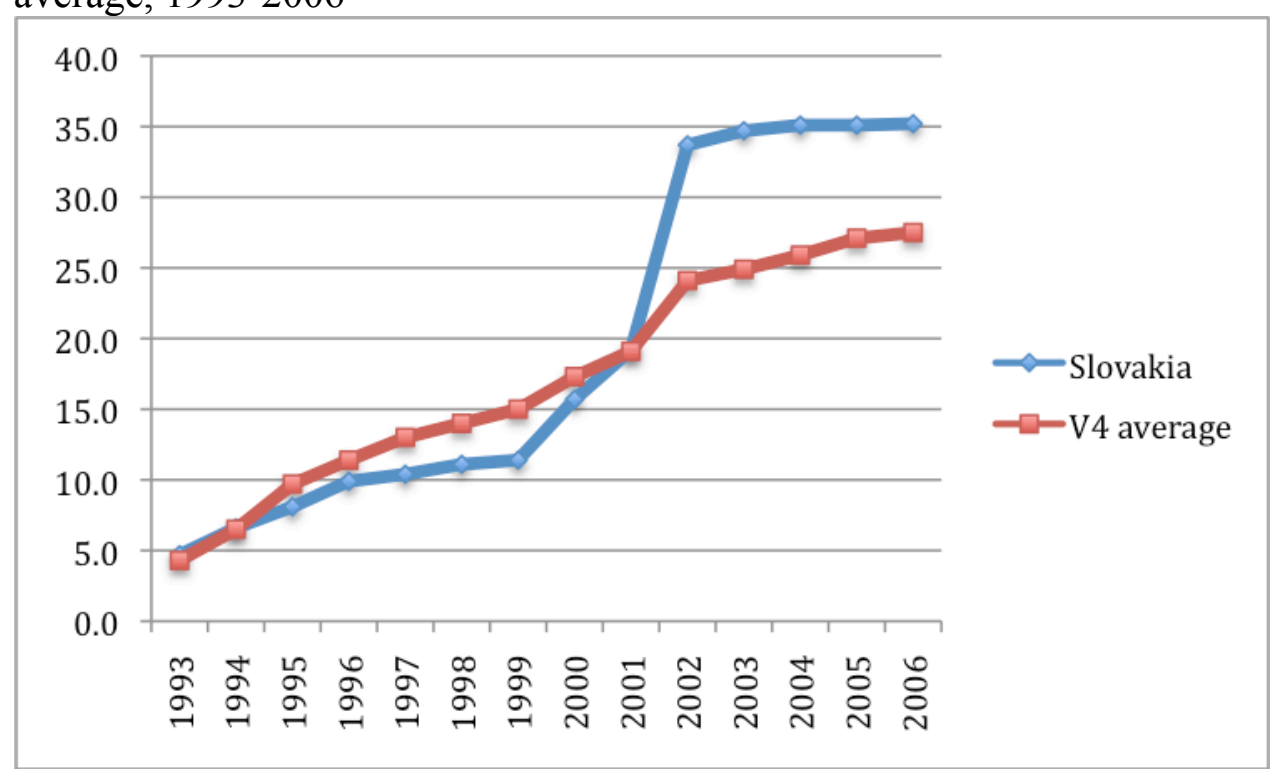

Source: EBRD

And finally, we add an indicator of foreign direct investment. Chart II.10 shows developments in net FDI on a per capita basis. Again, we can see that a major gap opened between Slovakia and its neighbors between 1994 and 19981 However, by 2000 Slovakia closed the gap and since then has actually been more successful than the average of its neighbors in attracting foreign investment.

Chart II.10: Net FDI in Slovakia vs the V4 average, in US dollars per capita, 19922006

\footnotetext{
${ }^{3}$ It is used in preference to the other frequently used statistic of the share of the private sector in GDP. The latter would be more precise, but unfortunately it is highly distorted because state-owned companies count as private as soon as they are transformed into private-law corporations. The privatization revenue data also have a problem in that they combine two underlying developments how much the government was privatizing and how much it was asking for its property. Nonetheless, as both are of interest, the time series is relevant.
} 


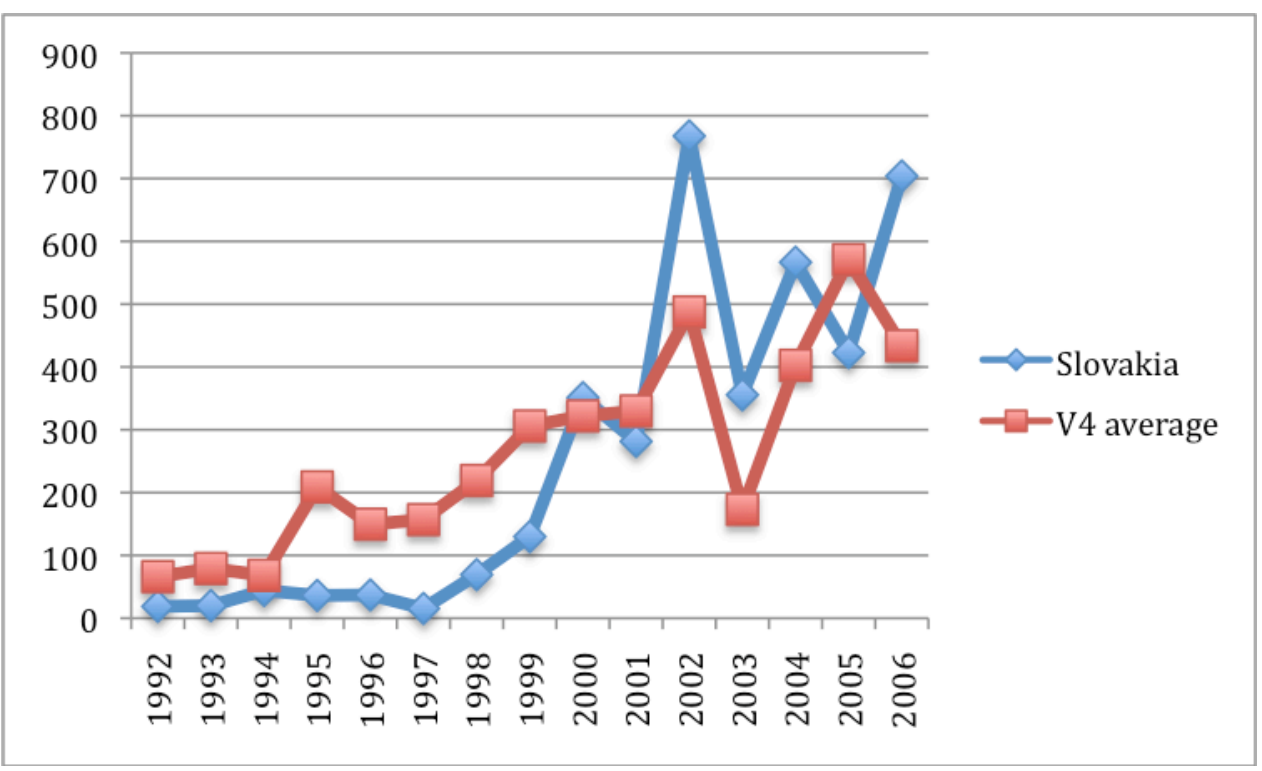

Source: EBRD

Overall, the data confirm that it was the Dzurinda I government that made the crucial shift in industrial policy, when Slovakia simultaneously restructured and privatized its banks and network industries, began to attract foreign direct investment and began to catch up with its neighbors in terms of industrial productivity. While the structural reforms of the Dzurinda II government and the continued emphasis on macroeconomic stability by the Fico government were important, with regard to the corporate sphere they built on these very firm foundations laid between 1999 and 2002. A result of the reforms is that Slovakia currently presents fewest obstacles in terms of business environment of all the Central European countries. According to the World Bank Doing Business survey, Slovakia is ranked around the $30^{\text {th }}$ place, while the other V4 countries rank 13 to 40 places behind it. This ranking was primarily achieved in 2004 and 2005, when Slovakia ranked among top reformers in the business environment.

Table II.5: Ranking in the Doing Business survey of the World Bank

\begin{tabular}{|l|r|r|}
\hline Country & 2007 & 2008 \\
\hline Czech Republic & 61 & 56 \\
\hline Hungary & 51 & 45 \\
\hline Poland & 68 & 74 \\
\hline Slovakia & 31 & 32 \\
\hline
\end{tabular}

Source: World Bank - Doing Business

\section{SECTION III: The World Bank Engagement with Slovakia}

Czechoslovakia rejoined the World Bank in 1990 as a part of its return to the Bretton Woods institutions. It took out a USD 450 million structural adjustment loan in 1991 to support the early stage of its reforms. This was also the only major World Bank project in Czechoslovakia before its dissolution. The newly independent Slovakia 
suffered from low foreign exchange reserves and external imbalance. The 1992-1994 Mečiar II government was therefore forced to several policy steps that it might otherwise not prefer (e.g. sale of the Slovak tobacco industry to a foreign investor). In this context, the two Bank projects approved in 1993 - Telecommunications Project and Economic Recovery Project - worth USD 135 million are more understandable and they constitute the only Bank financing for Slovakia until 2001. During the interim Moravčík government in 1994, negotiations on EFSAL, a loan intended to support bank restructuring, progressed significantly, but were ultimately unsuccessful because the Mečiar III government, which came to power at the end of 1994, was not interested in bank privatization as it ran counter to its philosophy of industrial policy.

Table III.1 shows all the World Bank loans in Slovakia between the independence in 1993 and 2008. As we can see, it was the period between 2001 and 2003 when most of the loans were approved, with two "laggards" approved later in 2005 and 2006.

Table III.1: World Bank loans in Slovakia (limited to projects that actually disbursed funding)

\begin{tabular}{|c|c|c|c|}
\hline PROJECT NAME & $\begin{array}{l}\text { APPROVAL } \\
\text { DATE }\end{array}$ & $\begin{array}{l}\text { CLOSING } \\
\text { DATE }\end{array}$ & $\begin{array}{l}\text { TOTAL } \\
\text { AMOUNT } \\
\text { (USD mil.) }\end{array}$ \\
\hline Telecommunications Project & 15-Jul-93 & 30-Jun-00 & 55 \\
\hline Economic Recovery Project & 30-Nov-93 & 31-Dec-95 & 80 \\
\hline $\begin{array}{l}\text { Enterprise and Financial Sector } \\
\text { Adjustment Loan (EFSAL) }\end{array}$ & 2-Aug-01 & 30-Jun-04 & 177.3 \\
\hline $\begin{array}{l}\text { Social Benefits Reform } \\
\text { Administration Project }\end{array}$ & $21-F e b-02$ & 31-Dec-07 & 23.54 \\
\hline $\begin{array}{l}\text { Public Finance Management } \\
\text { Project }\end{array}$ & 10-Jun-03 & 1-Jan-07 & 5.45 \\
\hline $\begin{array}{l}\text { Health Sector Modernization } \\
\text { Support Technical Assistance } \\
\text { Project }\end{array}$ & 11-Sep-03 & 30-Jun-09 & 12.38 \\
\hline Health Reform Project & 11-Sep-03 & 31-Mar-07 & 62.92 \\
\hline $\begin{array}{l}\text { Human Capital Technical } \\
\text { Assistance (SIDEM APL \#1) }\end{array}$ & 25-Jan-05 & 30-Jun-09 & 6.47 \\
\hline $\begin{array}{l}\text { Leader Preparation Technical } \\
\text { Assistance Project (under the } \\
\text { SIDEM Facility) }\end{array}$ & 2-Mar-06 & 30-Jun-08 & 1.5 \\
\hline
\end{tabular}

Source: World Bank

The table also demonstrates that, with the exception of EFSAL, the 2001-2006 Bank involvement was never important in financial terms either for the bank of for 
Slovakia. In a country where the fiscal expenditure is around USD 10 billion or more (depending on the year chosen for comparison), it would be difficult to argue that loans of USD 5-6 million or even USD 63 million are crucial macroeconomically. Nonetheless, the Bank was involved in nearly all the key sectors identified in previous sections: public finance, banking, health and social area. Obviously, (again with possible exception of EFSAL) its involvement could not and did not rely on conditionality - if you are lending relatively small sums of money, you do not have much leverage over the borrower. Rather, the Bank involvement was based on the fact that the key officials in the ministries concerned had similar views on policy as the Bank and used the Bank support and advise in implementing the policy views. The loans can thus be understood as a way of locking in the attention of the Bank and its staff and creating a flexible pot of money that could be used to purchase technical assistance. The former is based on the internal processes in the Bank, which make it difficult to sustain attention of its top staff on a country and one of its sectors, if there is no official project being undertaken. Therefore, even small projects could be a way of ensuring the continuing involvement and attention. The most iconic example of the latter is the Social Benefits Reform Administration Project, which was originally negotiated primarily to help overhaul the social security administration, but its most lasting achievement are the limited funds it provided in 2003 and 2004 for technical assistance related to the key policy and legal planks of the pension reform.

Additionally, looking at the World Bank engagement only through the prism of its lending activity is highly distorting. The Bank was active and influential in Slovakia throughout the 2000-2006 period also through two other instruments - analytical work and grant activity. With regard to the analytical work, the Bank has produced reports on issues ranging from agricultural markets to education. Probably only OECD (since Slovakia's membership in 2000) can come close to the quantity and quality of policy analysis outputs on Slovakia. The publications by the two institutions have always been a useful balance, not so much because of different philosophy, but because OECD tends to compare Slovakia with developed countries, while for the Bank developing and transition countries are the natural benchmarks. There is one topic deserving special attention though. True to its mission to eradicate world of poverty, two of the most detailed, ground-breaking and influential Bank studies for Slovakia focused on poverty and labor market. Published in 2001 and 2005 respectively, the two living standards studies still present unsurpassed studies of policies and their interaction with the socio-economic environment. (World Bank 2001, World Bank 2005)

Loans are not the only financial instruments at the Bank disposal. Strategic use of grants, particularly along with or in preparation for lending can also act as a powerful instrument of change, particularly if the country concerned is more in need of technical assistance than funds (which was the Slovak case as shown above). Again, two Bank grants stand out: Social Development Fund grant and the Legal and Judicial Reform grant. The former supported preparation of the Social Development Fund in Slovakia as a project- and community-based instrument for sustainable reduction in poverty. Even though the government ultimately decided to fund SDF activities from a combination of the public and EU funding, its rapid growth attests to the groundwork laid during the grant period. The latter was also intended to prepare the ground for technical assistance loan, which never materialized, but meanwhile it provided a significant level of advice and the analytical work, which the 2002-2006 
Ministry of Justice management utilized in its drive for judicial reform. A third, much more controversial example of the Bank grant activity is the grant provided during the 2005-2006 to the Government Office to support government communication of the Dzurinda II government reforms. The grant had clear rationale - the Bank supported the general thrust of the reforms and the biggest issues with the reforms were their problematic communication and rejection by important sections of the population. However, the line between supporting communication of reforms and political discourse is thin indeed and, in the view of the opposition at the time, the Bank involvement clearly crossed it. (BBC 2005)

Therefore, we can conclude that despite the relatively limited sums involved, the World Bank was highly engaged in Slovakia during the 2000-2006 period, with its fingers in all the crucial "pots". Since its views were mostly in sync with the key figures in charge of these portfolios, the relationship was based on genuine partnership.

After 2006 and the appointment of the Fico government, the nature of the relationship changed. This was not only due to the different political make-up of the incoming government, but also resulting from two other factors. One was the evolving nature of the Slovak transition. While there was a clear value added in the Bank involvement in completion of the country's transition, the nature of challenges for the post-2006 Slovakia were different. The second factor was the firm association between the Bank and the reforms of the Dzurinda II government in the eyes of the incoming government. The Fico government did not negotiate any new lending instruments, but that does not mean an absence of a relationship. For example, at the request of the Ministry of Finance, a major World Bank team conducted in early 2008 a confidential assessment of public finance challenges in key sectors. However, the key policy decision by the Fico government with regard to the Bank is the 2008 to graduate from the Banks assistance, shifting Slovakia from a potential recipient of financing to the donor camp.

\section{CONCLUSION AND CHALLENGES AHEAD}

The chapter briefly looked at socioeconomic changes experienced by Slovakia during its transition to the market economy. Even though there was a significant amount of continuity in certain policies during the whole transition, we were able to identify the 2000-2004 period as the time of rupture, when Slovakia in many key areas not only caught up with its neighbors in terms of the transition, but where it also significantly departed from them in new directions. Banking, industrial, fiscal, social and health policies all underwent radical change and, with the exception of healthcare, have remained roughly on the same path ever since.

The policies pursued during 2000s resulted in one of the fastest-growing economies in Europe and employment dropping from $20 \%$ to $10 \%$. On January 1, 2009, Slovakia will be the first country of the former Council of Mutual Economic Assistance (the Soviet economic bloc) to enter the eurozone. ${ }^{4}$ Despite the cut in the size of the state, poverty have dropped in recent years. When Slovakia came into existence in 1993 or

\footnotetext{
${ }^{4}$ Slovenia, which adopted the euro in 2007, was never a member of CMEA as the Yugoslav political and economic path was quite different from the rest of the Central and Eastern Europe
} 
even five years later, when a decisive change of government occurred in 1998, not many external observers predicted even a moderately successful country (see Beblavý and Salner 1999). Analysis of reasons why Slovakia managed to defy the pessimistic expectations is a subject fit for another paper, but the role of the World Bank was briefly addressed here. It is a cliché that domestic ownership of reform policies matters the most, but it follows that in the most successful countries, external actors do not matter as much as elsewhere. This is certainly true in Slovakia, where conditionality was not so relevant, but empowering reformers through provision of advice and policy dialogue certainly was. With this regard, the Bank found a successful niche that it managed to exploit to the fullest.

As for any successful postcommunist country, the story of Slovakia is also a story of how government began to matter less for the lives of the country's citizens. However, government policies will be a key determinant in answering the questions such as when will Slovakia reach or even surpass the EU average in terms of the standard of living and what kind of country it will be? Four issues stand out as crucial in this regard:

- macroeconomic stability

- physical infrastructure

- employment, social inclusion and skills

- innovation capacity

On the first two, the current situation is encouraging, but also contains difficult challenges. Preservation of macroeconomic stability after the eurozone entry will require flexibility in fiscal policy at levels not shown since 2003; despite extremely high and increasing growth, the country has not managed to cut the fiscal deficit from levels around $2 \%$ of GDP in 5 years. With regard to physical infrastructure, both Dzurinda II and Fico governments have given priority to the issue and increasing amounts of both private and public funding have been poured into transport, energy and ICT infrastructure. However, the strategy of the current government, combining Structural Funds and PPP in transport infrastructure with severe pressure on private investors in energy, requires highly sophisticated management to hold down uncertainty and ensure efficiency of public expenditure.

The other two challenges concern utilization of human resources by the Slovak economy. Despite the declining unemployment, the Slovak labor force contains approximately 150,000 people who have been unemployed for extended periods of time and have very low skills. Slovak education system has shown great flexibility in expanding supply of higher education, but concerns about quality and suitability of education provided to the young Slovaks for country's economic needs have become an important part of the public discourse. An even greater challenge is how to move Slovakia up the innovation chain both in terms of what is produced in Slovakia as well as whether the products are also invented and designed in the country. For both challenges, an important part of answer lies in the quality of public expenditure and public administration, particularly with regard to Structural Funds. While the EU funding began to flow to Slovakia already in 2004, the amount for the 2004-2006 period will be dwarfed by the influx during the 2007-2013 years. In some areas - such as the roads and railways - the EU money represents substantial addition to the existing budget. In others - in education, research and development, environment they are essentially the first large-scale public investment programs of the transition. 
As such, they represent a unique opportunity to ensure long-term success of the economy, but also a unique challenge to public administration unused to managing such inflows effectively and efficiently.

The World Bank has experience in assisting countries dealing with these issues from its collaboration with middle-income countries. Therefore, a continuing policy dialogue between Slovakia and the Bank - learning from the Slovak successes and failures and helping Slovakia to be successful in its quest to catch-up with Western Europe - can be useful for both sides even as the country moves from recipient to donor status.

\section{REFERENCES}

BBC 2005. Vysvetl'ovanie reforiem, či politická kampaň. BBCSlovak.com - October 13, 2005. Accessed on August 29, 2008 at: http://www.bbc.co.uk/slovak/news/story/2005/10/051013_svk_strategicalplan.shtml

Beblavý, M and A. Salner 1999. Tvorcovia obrazu a obraz tvorcov: Vnímanie Slovenska v západných krajinách. CSMA: Bratislava

European Commission 2006. The long-term sustainability of public finances in the European Union. European Economy 4/2006

MoLSAF 2003a. Návrh stratégie podpory rastu zamestnanosti prostredníctvom zmien sociálneho systému a trhu práce. Ministry of Labor, Social Affairs and Family: Bratislava

MoLSAF 2003b. Návrh koncepcie reformy dôchodkového zabezpečenia v SR. Ministry of Labor, Social Affairs and Family: Bratislava

OECD 1999. Economic Surveys: Slovakia. OECD: Paris

Tošovský, J. 1996. Disinflation in the Czech Republic: Looking Both Backward and Forward. Federal Reserve Bank of Kansas City; August 1996.

Tóth, J. 2000. Fiscal Policy. In Marcinčin, A. and Beblavý, M. (eds.) Economic Policy in Slovakia 1990-1999, CSMA and SFPA: Bratislava

World Bank 2001. Slovak Republic - Living standards, employment, and labor market study. World Bank: Washington, D.C.

World Bank 2005. The Quest for Equitable Growth in The Slovak Republic: Living Standards Assessment. World Bank: Washington, D.C. 